İş ve Íns an Dergisi I The Journal of Hu man and Work

Y11 | Year: Ekim | October 2017

Cilt-Sayı | Volume-Issue: 4 (2)

ss I pp: 87-99

doi: 10.18394/iid.280529

e-ISSN 2148-967X

http://dergipark.gov.tr/iid/

Araştır ma Makalesi

\title{
Öznel Kariyer Başarısı: Bir Ölçek Uyarlama Çalışması
}

\author{
Subjective Career Success: A Scale Adaptation Study
}

Gökhan Budak*, a , Sait Gürbüz ${ }^{\text {b }}$

\section{MAKALE BILGIISI}

Anahtar Kelimeler:

Öznel kariyer başarısı, Ölçek uyarlama, Güvenilirlik,

Geçerlilik.

\section{Tarihler:}

Geliş 23 Aralık 2016

Düzeltme geliş 04 Nisan

2017

Kabul 29 Nisan 2017

\section{ÖZ}

Öznel kariyer başarısı; işgörenin yaptı̆̆ işten ve kariyerinden gurur duyması, hayatındaki en önemli hedeflerini gerçekleştirmesi, iş-yaşam dengesi să̆laması ve huzur duymasi gibi göstergelere vurgu yapmaktadır. Bu çalışmanın amacı; Shockley, Ureksoy, Rodopman, Poteat ve Dullaghan (2015) tarafindan geliştirilen, 'tanınma', 'işin niteliği', 'işsin anlam lılı̆̆ı', 'etki', 'otantik', 'kişisel yaşam', 'büyüme ve gelişme' ve 'tatmin' olmak üzere sekiz boyut ve 24 maddeden oluşan Öznel Kariyer Başarısı Ölçeğinin Türkçeye uyarlanmasını yaparak, ölçeğin güvenilirlik ve geçerliliğini test etmektir. Calıșma kamu $(N=366)$ ve özel sektör $(N=373)$ olmak üzere iki farklı örneklem den alınan verilerle yürütülmüş̧ür. Yapılan analiz çalışmalarından elde edilen bulgular, ölçeğin alt boyutlarının güvenilirlik katsayılarının 0.79 ile 0.91 arasında değiştiğini göstermiştir. Ayrıca yapılan faktör analizi sonucunda, "tanınma", "işin niteliği", "işin anlamlılı̆̆l", "etki”, "otantik", "kişisel yaşam”, "büyüme ve gelişme"ve "tatmin" boyutlarını içeren sekiz faktörlü yapı doğrulanmıştır. Netice olarak güvenilir ve geçerli bir ölçüm aracı olan ölçeğin Türkiye'de yapılacak araştırmalarda kullanılabilir olduğu saptanm ıştır.

\section{A RTICLE INFO}

\section{Keywords:}

Subjective career success, Scale adaptation, Reliability, Validity

Article history:

Received 23 December 2016 Received in revised form 04 April 2017

Accepted 29 April 2017

\begin{abstract}
A B STRACT
Subjective Career Success underlines these points such as being proud of an employee of his job and career, achieving the most important goals, providing work-life balance and feeling tranquility him self in job. The main purpose of this study is to examine the Turkish adaptation of subjective career success scale explored by Shockley, Ureksoy, Rodopman, Poteat and Dullaghan (2015) which consists of 24 items and eight dimensions "satisfaction", "growth and development", "personal life", "authenticity", "influence”, "meaningful work”, "quality work", "recognition" and to test validity and reliability of it. The sample is composed of both public sector and private sector. The findings show that the reliability coefficients of the sub dimensions of the scale varied between 0.79 and 0.91. Moreover, the results of factor analysis confirmed the fit of the eight factor model measuring the "satisfaction", "growth and development", "personal life", "authenticity", "influence”, "meaningful work", "and quality work", "recognition". Ultimately, it was determined that the scale is a reliable and valid measurement scale and it can be used in studies in Turkey.
\end{abstract}

\footnotetext{
", a İletişim Kurulacak Yazar, Milli Savunma Üniversitesi, Alparslan Savunma Bilimleri Enstitüsü, Ankara, Türkiye.gbudak@kho.edu.tr. ORCID: 0000-0001-8143-2857

${ }^{b}$ Prof. Dr., Ankara Sosyal Bilim ler Üniversitesi, Ankara, Türkiye. ORCID: 0000-0001-7817-9141
} 


\section{GİRIŞ}

İşgörenler ve örgütler açısından önemli sonuçları olan kariyer başarısı, örgütsel davranış ve insan kaynakları yönetimi alanında çalışan araştırmacıların ilgisini çekmeye devam eden konulardan birisidir. Geleneksel kariyer anlay ışında kariyer başarısı, örgütün hiyerarşi kademelerinde yükselmek (terfi) ve daha fazla para kazan mak gibi genellikle maddi ve dişsal özendiriciler ile ifade edilmektedir (Gattiker \& Larwood, 1986). Geçmiş dönemde yapılan çalışmalara bakıldığında bu anlayışı in kariyer başarısı konusunda yapılan araştırmalara da yansıdığı görülmektedir. Örneğin yapılan bir inceleme çalışmasında, kariyer başarısı konusunda 1980-1994 yılları arasında yayımlanan araştırmaların \% 75 'inden fazlasında nesnel kariyere odaklanıld ı̆g 1 tespit edilmiştir (Arthur \& Rousseau, 1996).

Ancak son yıllarda yaşanan kademe azaltma, küçülme ve diş kaynaklardan yararlanma gibi gelişmeler, günümüz örgütlerinde unvan, terfi ve istikrarlı kariyer yolları gibi dışsal ya da nesnel kariyer başarıs1 göstergelerin in var olma olasılığın 1 azaltmaktadır. Çünkü artık günümüzün örgütlerinde dikey kariyer hareketliliklerinden ziyade daha çok yatay hareketlilikler görülmektedir (Arthur, Khapova \& Wilderom, 2005). Bu değişimlere paralel olarak geleneksel kariyer anlayışının yerini, sınırsız kariyer anlayışı almaya baş la mıştır. Sın ırsız kariyerdeki başarı kriteri ise kişinin kendi değerleri ve kariyer hedefleri doğrultusunda kariyer başarısını değerlendirmesi anlamına gelen öznel başarıy gerçekleştirmektir. Öznel kariyer başarısı, genel olarak "yaşamaya değer bir hayata sahip olma" olarak tanımlanmaktadır (Hall, 1996). Ayrica yüksek ücretinden dolayı ekonomik durumu iyi olan, çalıştığ diğer insanlar tarafindan kariyerlerinde başarılı kabul edildikleri görüldüğünden dolayı, araştırmacıların da konuya nesnel kariyer başarısına odaklan maları şaşırtıcı görülme mektedir ( $\mathrm{Ng}$, Eby, Sorensen \& Feldman, 2005). Ancak bireylerin kariyer başarılarını belirtirken sadece aldıkları ücret, terfi, statü vb. hususlara vurgu yapmadikları, kariyerleri ile ilgili öznel hususları da belirttikleri görülmektedir (Sturges, 1999). Bu nedenle kariyer başarısı algısında çoğunlukla göz ardı edilen öznel boyutunun da araştırılmaya başlandığ görülmektedir.

Öznel kariyer başarısı işgörenin yaptığı işten ve kariyerinden gurur duymas1, hayatındaki en önemli hedeflerini gerçekleştirmesi, iş-yaşam dengesi sağlaması ve huzur duyması gibi göstergelere vurgu yapmaktadır. Öznel kariyer başarısı konusunda yapılan son dönemdeki çalışmalar, öznel kariyer başarısının tek boyutlu olarak ele alınmasının yeterli olmayacağını öne sürerek çok boyutlu öznel kariyer başarısı kavramını ortaya atmışlardır (Shockley vd., 2015). Bu kapsamda, çok boyutlu öznel kariyer başarısı yaklaşımının, öznel kariyer başarısının anlaşılmasına ve bu konuda yapılacak görgül araştırmaların genişlemesine önemli katk1 sağlamas1 beklenmektedir. Buna rağmen bu araştırmanın tasarlandığ Türkiye'deki örgütsel davranış araştırmalarında öznel kariyer başarısını ele alan herhangi bir kuramsal ya da görgül bir çalışmaya rastlanıla mamıştır. Türkiye'de öznel kariyer başarısı konusunda yapılacak görgül araştırmaların gerçekleştirilmesi, her şeyden önce bu konuda uygun psikometrik özelliklere sahip ölçeklerin varlı̆ ina bağlid ır. Söz konusu ihtiyaçtan hareket ederek bu çalışmanın temel amacı; Shockley ve ark. (2015) tarafından geliştirilen çok boyutlu öznel kariyer başarısı ölçeğinin Türkçeye uyarlamasını ve geçerle mesini yap maktır.

$\mathrm{Bu}$ çalışmanın iki temel katkısının olacağ 1 beklen mektedir. Birincisi, oldukça yeni bir kav ram olan çok boyutlu öznel kariyer başarısının ölçümü için geliştirilmiş bir ölçeğin sistematik bir süreç ile Türkçeye uyarlanması ve geçerlemesi yapılacaktır. Böylelikle söz konusu ölçeğin ulusal yazına kazandırılması ve öznel kariyer başarısı konusunda bundan sonraki araştırmalar için bir başlangıç oluşturması düşünülmektedir.

İkincisi, bazı araştırmalarda yönetim ve örgüt alanındaki ölçeklerin Türkçeye uyarlama süreçlerinde bazı metodolojik sorunların olduğu öne sürülmüştür (Örneğin Bayık \& Gürbüz, 2016; Erdemir, 2008). Bu çalışmada Bay lk ve Gürbüz (2016) tarafından ölçek uyarlama sürecine yönelik olarak önerilen sistematik temel adımlar takip edilecekt ir. Dolayısıyla, bu çalışman in Türkiye'de yapılacak olan ölçek uyarlama çalışmalarına metodoloji birliği sağlama bakımından mütevazı bir katkı sağlayacağ beklenmektedir.

\section{KAVRAMS AL ÇERÇEVE}

\subsection{Kariyer Başarısı}

Kariyer kavramı gündelik yaşamda sıklıkla kullanılan bir kavramdır. Ancak bu kavram birçok insan tarafindan farklı biçimde ifade edilmektedir. $\mathrm{Bu}$ ifade farklılıkları kariyer başarısının da farklı biçimde açıklanmasına neden olmaktadır. Kavramsal açıdan kariyer kavramının netlik kazanması, başarı alg ılamaları ile ilg ili farklılıkları da yansitmaya imkân sağlamaktadır. Yazında kariyer başarısının genellikle maaş ve terfi gibi 
nesnel faktörlerle ölçüldüğü görülmektedir (Hall, 2002). Ancak kariyer tatmini konusunda nesnel faktörler günümüzün çağdaş örgütlerinde çalışan işgörenleri tatmin etme konusunda yeterli olmamaktadır. Çünkü artık günümüzün örgütlerinde kariyer geçişleri dikeyden ziyade daha çok yatay geçişler olmaktadır. Aynı zamanda beklenen yaşam süresinin artmasılyla birçok işgören çok yönlü veya sınırsız kariyer düşüncesini benimsemektedir (Arthurvd., 2005).

Hall (2002), kariyerin dört farklı anlama sahip olduğunu belirtmektedir. Kariyer birinci anlamı ile bir ilerlemeyi ifade etmektedir. Bu ilerleme örgütsel hiyerarşi içerisinde yükselmedir. İkinci anlamı ile bir mesleği ifade etmektedir. Bazı meslekler, kariyer meslekleri olarak adlandırılmaktadırlar. Bu mesleklere sahip olmak bir saygnnlık göstergesi ve başka kariyer yollarına sahip olman ın da aracısıdır. Üçüncü anlamı ile kariyer, insanların yaşamları boyunca birçok mesleği yerine getirdikleri, her bir mesleği yerine getirirken belirli deneyimler elde ettikleri ve bu mesleklerde içsel olarak da tatmin olmaların 1 içeren bir anlama vurgu yapmaktadır. Son olarak kariyer, birey in yaşam boyunca yaptığ 1 mesleklerin sahip olduğu rollerin ardışık bir nite liğe sahip olmasin1, bu rol ve mesleklerin bireyin gelişimine ve doyum elde etmesine katkı sağ laması anlaminda kullanılabilmektedir.

Greenhaus (2003) kariyeri, bir kişinin yaşamı boyunca karşılaştığ 1 ișle ilgili deneyimler ve faaliyetler ile ilg ili a lgılanan tutum ve davranışların bireysel algılanma süreci olarak tanımlamaktadır. Seibert ve Kraimer (2001)'a göre kariyer başarısı; kişinin, iş deneyimlerin in bir sonucu olarak elde ettiği başarıların, pozitif psikolojik sonuçlar ya da işle ilişkili sonuçların bir toplamıdır. Kariyer başarısının sonuçlarına bakıldığında, hem bireyi hem de örgütleri ilgilendirdiği görülmektedir. Çünkü bireylerin kişisel başarısı örgütsel başarıa da katkıda bulunmaktadır (Judge, Higgins, Thoresen \& Barrick, 1999).

Günü müzde kariyer başarısı denild iğinde akla terfi ve maaş gibi nesnel faktörler gelmektedir. Araştırmaların çoğu kariyer başarısını ölçmek için bir veya birkaç boyut kullanmaktadır. Gattiker ve Larwood (1986) kariyer başarısını; iş başarısı, kişisel başarı, maddi başarı, hiyerarşik başarı ve yaşam başarısı şeklinde beş başlık altında incelemektedir. Elliott (1982) ise kariyer başarısını hiyerarşik seviye ve ücret birleşimi olarak tanımlamaktadır. Dyke ve Murphy (2006), kariyer başarısını; iş ve aile yaşamı dengesi sağlama, ilişkilere sahip olma, diğerlerince kabul görme ve maddi kazanımlar elde etme, șeklinde dört başlık altında ifade etmektedirler. Heslin (2005), kariyer başarısının ödeme ve terfi gibi nesnel sonuçlarının olduğunu, iș doyumu ve kariyer doyumu gibi öznel sonuçlarının olduğunu, bireyden bireye değişkenlik gösteren öznel yönünün olduğunu ve bireylerin kendilerini referans aldıkların1 belirtmektedir. Çünkü sosyal karşılaştırma kuramına göre insanlar kendilerini başkalarıy la kıyaslama eğilimindedir (Festinger, 1954). İnsanların emsallerine göre daha fazla ücret ve terfi alması bireyin başarı alg $1 \mathrm{~s}$ in artırmakta ve bu durum kariyer başarısını daha fazla his setmes ine yardımc1 olmaktadır.

\subsection{Nesnel ve Öznel Kariyer Başarısı}

Nesnel ve öznel kariyer başarısı kav ramları, ilk kez Hughes (1937) tarafindan ortaya atılan nesnel ve öznel kariyer kavramlarına dayanmaktadır. Hughes (1937), öznel kariyerin kişinin, nesnel kariyerin ise toplumun bakış açısı tarafindan şekillendirildiğini ifade etmektedir. Buna göre Hughes'in (1937) nesnel kariyeri, üçüncü kişiler tarafından doğrudan gözlemlenip ölçülebilen ve doğrulanabilen kariyer olarak, öznel kariyeri ise sadece o kariyere sahip olan kişi tarafından doğrudan deneyimlenebilen kariyer şeklinde tanımladığ 1 görülmektedir. Hughes'in (1937) nesnel ve öznel kariyere ilişkin yaptığı bu tanımlar doğrultusunda nesnel kariyer başarısı, ücret, terfi, statü gibi toplum tarafından gözlemlenebilen faktörlerle açıklanırken, öznel kariyer başarısı kişin in kendi kariyer deneyimlerine ilişkin tepkileri olarak tanımlanmaktadır. Nesnel kariyer, tanımlanabilir pozisyon, unvan ve statülerle ifade edilirken, kişinin kariyerine ilişkin kendi tecrübeleri de öznel kariyer olarak ifade edilebilir. Başka bir deyişle öznel kariyer, kişinin kariyerini nasıl anla mlandırd ığına iliş kindir.

Sturges (1999), kariyer başarısı konusunda yaptığ çalış mada kariyer başarısını, ö znel başarı ve nesnel başarı şeklinde iki başlık altında ele almıştır. Ayrıca yöneticileri, tırmananlar, uzmanlar, etki bırakanlar ve kendini gerçekleştirmek isteyenler şeklinde ifade etmektedir. Turmananların temel kariyer başarısı kriterlerini, hiyerarşik yükselmeler ve maddi kazanımlar şeklinde ifade etmektedir. Uzmanların temel kariyer başarısı beklentilerini, işinde üst düzey becerilere sahip olma, diğerlerince işinde uzman şeklinde değerlendirilme ve onlardan sayg1 görme, şeklinde ifade etmektedir. Etki bırakanların temel kariyer beklentilerin i ise, ille de hiyerarşik bir pozisyona ihtiyaç duymaksızın, örgüt ve diğer çalışanlar üzerinde somut ve olumlu etkiler bırakabilme, şeklinde ifade etmektedir. Kendini gerçekleştirmek isteyenlerin temel kariyer beklentilerini ise; kişisel düzeyde öznel olarak başarı duygusunu yakalama şeklinde ifade etmektedir.

$\mathrm{Ng}$ ve arkadaşları (2005), kariyer başarısını, kişinin iş deneyimleri sonucu işle ilgili elde ettikleri veya 
psikolojik nitelikteki olumlu çıktılar olarak açıkla maktadır. Bu tanımından da anlaşılacağı üzere hem nesnel hem de öznel olmak üzere iki farklı yönü bulunmaktadır. Zaten kişilerin kariyerlerine ilişkin hayal ve beklentilerinin birbirlerinden farklılık gösterdikleri göz önüne alındığında, aynı istihdam koşullarında bulunan kişilerin aynı öznel kariyer yönelimlerine sahip olmaların 1 beklemek yanlış olacaktır.

Kariyer yazın 1 alanında çalışma yapan araştırmacılarla kariyer başarısını tanımlamak amacıyla yapılan çalış mada Hes lin (2005) kariyer başarısının karmaşıklığına dikkat çekmiştir. Heslin öncelikle başarı kriteri olarak kariyer başarısının öncülleri hakkında bir kitlık olduğunu belirtmektedir. Heslin'e göre bu eksiklikler neticesinde nesnel ve öznel kariyer başarısına daha geniş kapsamlı bakılması gerekmektedir. Aynı çalışmada kariyer alanında çalışma yapan araştırmacılardan Nicholson ve Waal-Andrews nesnel ve öznel kariyer başarısı ayrımın ın önemli olduğunu söylemekle beraber potansiyel bir yanlış bilgi kaynağ 1 olduğunu belirtmektedir (aktaran Heslin, 2005). Onları bu düşünceye iten sebep ise nesnel kariyerin ve amaçların in öznel kariyerden önce gelmesi ve öznel kariyeri gizlemekte olduğudur. Nicholson ve Waal-Andrews insanların nesnel başarıya sahip olmadığ 1 halde mutlu insanlar olduğu gibi, nesnel başarıya sahip olup mutlu olmayan insanlar olduğunu belirtmektedir (aktaran Heslin, 2005).

Araştırmacılar nesnel kriterler olarak doğrudan gözlemlenebilir, kolaylıkla ölçülebilir olan kriterlerde birleşmekte ve nesnel kariyer başarısı bireylerin başarı sonuçlarının dönüm noktası olarak görülmektedir (Heslin, 2005). Ancak nesnel olarak ücret ve statülerine göre kariyerleri başarılı bulunan çoğu kişinin, kendilerini kariyerlerinde başarılı hissetmedikleri görülmüştür (Hall, 2002). Çünkü ücret ve statü, kariyer başarısında önemli ve arzu edilen çıkt ılar olmalarına rağ men kariyer başarısının sadece bir parçasını oluşturmaktadır. Buna göre kişilerin kariyer hedefleri, değer yargıları ve hayallerine göre de kendilerini başarılı hissetmek istedikleri belirtilmektedir. Öznel kariyer başarısı ise bireyin kariyer ilerlemesinin kendi değerlendirmesini, bireyin öznel alg 1 sını ve kariyerini değerlendirmesini içeren daha üstü kapalı veya örtük olarak tanımlanmaktadır (Ng \& Feldman, 2014). Hall (1996) ise öznel başarıy1, Shepard'in (2010) kişilerin potansiyellerini sadece yüreklerin in seslerini dinlemeleriyle (path with a heart) gerçekleştirilebilecekleri görüşü üzerine kurmuş ve başarıyı da "yaşamaya değer bir hayata sahip olma" (life fully worth living) olarak tanımlayarak bu eksik kalan yönü tamamlayıcısını sunmaktadır. Buna göre öznel başarıya ilişkin göstergeler, kişinin gurur duyması, hayatındaki en önemli hedeflerini gerçekleştirmesi, aile mutlu luğunu sağlaması ve huzur duyması vb. olarak sayılmaktadır.

\section{3. Öznel Kariyer Başarısının Boyutl arı}

Greenhaus, Parasuraman ve Warmley (1990)'a göre kariyer tatmini bireyin kariyer amaçlarına doğru dört alanda ilerlemesi olarak kabul edilmektedir. $\mathrm{Bu}$ alanlar; b irey in bütün kariyeri, geliri, ilerle me (terfi) ve yeni yetenekleri alanında elde ettiklerini kapsamaktadır. $\mathrm{Bu}$ hususlar dikkate alındığ inda kariyer tatmini, öznel kariyer başarısı için önemli parçaları oluşturmakta ancak tek başına da yeterli görünmemektedir. Turban ve Doughtery (1994) kariyer başarısını tüm başarı algısı olarak alması kişinin tamamen bireysel değerlendirmesi yönüyle tek boyutlu olarak incelemesinden dolayı eksik kalmaktadır. Bu nedenlerden dolayı öznel kariyer başarısına çok boyutlu bir yaklaşımla bakılması daha uygun bir yaklaşım gibi gözükmektedir. Yazında öznel kariyer başarısı performans, örgüt içinde diğer bireyle re nüfuz etme, finansal faktörler, ilerleme(terfi), çalışma hayatının ötesinde sosyal hayat, gelişim, otonomi, tatmin, sayg1 ve anlamlı olması gibi faktörlerin etkili olduğu görülmektedir. Gattiker ve Larwood (1986) çalışmalarında öznel kariyer başarısı; iş başarısı, kişilerarası başarı, finansal başarı, hiyerarşik başarı ve yaşam başarısı olmak üzere beş boyutta ele alınmaktadır. Bu boyutlardan ilk dördü örgütsel başarının parçası olarak düşünülebilirken yaşam başarısı örgütsel olmayan başarı olarak düşünülebilir. Parker ve Arthur (2002) işletme yüksek lisans öğrencilerine yaptığı odak grup çalışmasında ortaya çıkan başarı faktörleri; (1)destekleyici çalışma atmosferi, istikrar, lider, koç, geri bildirim aracılı̆̆ $1 y$ la öğrenme, (2) şirkete özel ilişkiler; bireylere nüfuz etme , (3) dışsal ilişkiler; çalış ma hayatının ötesinde sosyal hayat, (4) yenilen me, bilgi ve beceri; yeni bilgi ge lişimi, (5) esneklik; otonomi, (6) beğenme; sayg1, sosyal kabul, projeler anlamlı olması ile iliş kilendirileb ilir.

Yazında öznel kariyer başarısının genellikle hangi faktörlere göre değerlendirildiğ $i$ incelendiğinde ise; karşımıza kariyer ve iş tatmini olguları çıkmaktadır. Ancak kariyerlerini başarılı bulan kişilerin, tatmin olmadıkları bir işe geçtiklerinde kariyerlerini başarılı bulmaya devam edebildikleri veya şu andaki işlerinden yüksek düzeyde tatmin olan kişilerin ise kariyerlerini başarılı olarak nitelendire meyebildikleri saptanmıştır. Bu nedenle öznel kariyer başarısının, iş ve kariyer tatmininden çok daha karmaşık bir kavram olduğu ve kimlik duygusu, iş-yaşam dengesi, sağlik ve diğer kişisel değerler gibi unsurları da içerdiğ i ifade edilebilir (Heslin, 2005). Başka bir deyişle kişilerin, kariyer 
başarılarını değerlendirme lerinde odak noktalarının işin kendisinden yaşamı kendisini değerlendirmeye kaydığ 1 da ifade edilebilir. Hall (2002)' in da öznel kariyer başarısını, kişinin ailesi, iş arkadaşları, çalıştığ toplumun kriterlerinden ziyade kendisine anlamlı gelen hedefleri gerçekleştirmesi deneyimi olarak tanımladığ1 görülmektedir. Hall (2002) öznel kariyer başarısını, kişinin elinden gelenin en iy isini yaptığını bilmesinden kaynaklanan gurur duygusu olarak tanımlamaktadır.

Çok boyutlu öznel kariyer başarısı ölçeğine neden gerek duyulduğunun kuramsal ve görgül nedenleri şu şekilde sıralanabilir (Shockley vd., 2015). : İlk olarak günümüzün örgütlerinde kariyer hareketliliğin dikeyden ziyade yatay şekilde olması, örgütlerin küçülmeye ve dış kaynaklardan yararlan maya doğru geliş melerin olması nedeni ile kariyer başarısında nesnel faktörlerden ziyade öznel faktörlerin göreli önemi artmıştır. İkinci olarak, aynı yapıyı ölçmek için daha önce Gattiker ve Larwood (1986) tarafından geliştirilen ölçeğin üzerinden yaklaşık otuz yıl geçmiş olması ve son yirmi y 1 lda iş gücündeki demografik değiş kenlerin ve işlerin yapısında meydana gelen değişimlerin işgörenlerin kariyer davranışlarında ve algılarında değişim oluşturduğu iddiasıdır (Sullivan \& Baruch, 2009).

Shockley ve arkadaşların ın (2015) 2003-2014 yılları arasında yaptıkları çalışmada, çalışmaların \% 46'sının nesnel kariyer başarısını kariyer tatmini, \% 24'ünün tamamen başarı algısı ve \%4'ünün her ikisini kapsayacak şekilde ele alındığ 1 tespit edilmiştir. Shockley ve arkadaşlarının (2015) ölçek geliştirme çalışması (1) mülakat ve odak grup görüşmesi, (2) konu uzman ları ile açık uçlu tarama, (3) madde havuzunun oluşturulması ve (4) ölçeğin güvenilirliğinin ve geçerliliğinin tespiti olmak üzere dört safhadan oluşmaktadır.

\section{YÖNTEM}

Ölçek uyarlama konusunda Türkiye'de yapılan araştırmalarda, yabancı dilde geliştirilen ölçeklerin Türkçeye uyarlanması sürecine gerekli özen gösterilmediğine dair bazı araştırma bulguları bulunmaktadır. Örneğin yönetim ve örgüt alanındaki kongre bildirilerini (2002-2007 y1llar1 aras1) inceleyen Erdemir (2008); bildirilerin \% 49'unda ölçeklerin uyarlanmadan doğrudan doğruya çevirisinin yapılarak kullanıldığ 1 , \% 26 'sında hem uyarlama çalışması yapılmadı̆̆ 1 hem de kullanılan ölçeğ in kaynağının belirtilmediğini tespit etmiştir. $\mathrm{Bu}$ araştırmada ölçek uyarlama ve geçerleme çalışması, ilgili yazın (örneğin Brislin vd., 1973; Ægisdóttir vd., 2008) ve Uluslararas1 Test Komisyonu'nun (International Test Commission-ITC) ilkeleri dikkate alınarak Bayık ve Gürbüz (2016) tarafından geliştirilen beş aşamalı model takip edilerek yapılmıştır. Buna göre çalış ma; (1) ölçeğin hedef dile çevrilmesi, (2) hedef dile çevrilen ölçeğ in hedef dilden orijinal dile geri çevrilmesi, (3) uzman / hakem görüşüne başvurulması, (4) ön test yapılması, (5) ölçeğin güvenilirliğinin ve geçerliliğ inin değerlendirilmesi aşamalarından oluşmaktadır.

\subsection{Ceviri Çalıșması ve Ön Test}

Çalışmada kullanılan Öznel Kariyer Başarısı Ölçeğ inin (Shockley vd., 2015) Türkçeye çeviri aşamasında ilgili yazın (örneğin Brislin vd., 1973; Ægisdóttir vd., 2008) ve Uluslararas1 Test Komisyonu'nun (International Test CommissionITC) ilkeleri dikkate alınarak Bayık ve Gürbüz (2016) tarafından geliştirilen ve yukarıda belirtilen beş aşamalı modelin ilk dört aşaması uygulanmıştır. $\mathrm{Bu}$ aşamalar (1) ölçeğin hedef dile çevrilmesi, (2) hedef dile çevrilen ölçeğin hedef dilden orijinal dile geri çevrilmesi, (3) uzman/hakem görüşüne başvurulması ve (4) ön test yapılmasinı içermektedir. Öznel Kariyer Başarı Ölçeği öncelikle iki İngiliz dili ve edebiyatı öğretim üyesi tarafindan Türkçeye çevrilmiştir. Elde edilen Türkçe ölçek, Türkçeye ve İngilizceye hâkim örgütsel davranış alanında çalışan üç uzman tarafından değerlendirilmiştir. Değerlendirme sonucunda elde edilen Türkçe ölçek, farklı iki İngiliz dili ve edebiyatı öğretim üyesi tarafından tekrar İngilizceye çevrilmiştir. Elde edilen İngilizce ölçek, özgün haliyle karşılaştırılmış ve son olarak iki uzman görüşüne sunulmuştur. Uzman değerlendirmeleri sonrasında ölçeğin son hali ortaya çıkmış ve mevcut çalışmada kullanılması kararlaştırılmıştır. Ön test aşamasında belirlenen odak gruptaki katılımcıların her bir maddeye ne anlam yükledikleri görüşülerek gerek görülen maddelerin ifade ediliş şekilleri değiştirilmiştir. Örneğin "Tanın ma” boyutunun ilk maddesinde bazı katılımcılar 'A mirlerim yaptığım işlerden dolayı takdir etmektedir.' şeklinde anlam yükler iken bazıları 'A mirlerim yaptığım işlerde başarılı olduğumu ifade etmektedirler.' şeklinde anlam yüklemişlerdir. Bunun sonucunda da maddenin ifade ediliş şekli 'A mirlerim iyi iş çıkardı̆̆ımı söylerler.' şeklinde değiştirilmiştir. Ölçeğ in nihai hali Ek-A'da verilmiştir.

\section{2. Ölçeğin Güvenilirliğinin ve Geçerliliğinin Değerlen dirilmesi}

$\mathrm{Bu}$ çalış mada ölçeğin geçerlilik ve güvenilirliğ inin değerlendirilmesi kamu ve özel sektörde çalışan işgörenlerden oluşan iki farklı örneklem üzerinden yapılmıştır. İki ayrı örneklem üzerinde 
çalışılmasının nedeni kamuda çalışan işgörenlerden elde edilen verilerle yazında kabul edilen eşik değerler elde edilememiş ve ölçeğin yapısı doğrulanamaması nedeniyle özel sektörde çalışan işgörenlerden oluşan ikinci örneklemden veri toplanmıştır.

\subsubsection{Araştırma I}

Örneklem. Çalışmanın ilk örneklemi, Türkiye'deki ulusal güvenlikten sorumlu bir kamu kuruluşunda görev yapan ve rastlantısal olarak oluşan 366 katılımcıdan oluşmaktadır. Katılımeıların 349' u erkek (\%95), 17’si kadındır (\%5) ve yaşları 26 ile 37 arasında değişmektedir. Bireylerin yaş ortalamas1 31,62 olup, \%85'i evli, \% 15'i bekârdır. Eğ itim dü zeyi açısından bakıldığında \%1'i doktora, $\% 10$ 'u yüksek lisans, \%61'i lisans, \%17'si ön lisans ve \%9'u lise mezunudur. Bireylerin ortalama hizmet süreleri 9 yıl olarak belirlen miştir. Kolayda örneklem tekniğ inin seçildiğ i çalş̧ma için anket tekniği kullanılmış ve anketler yüz yüze icra edilmiştir.

Veri Toplama Aract ve Işlem. Shockley ve ark. (2015) tarafından geliştirilen ve bu makalenin yazarları tarafından Türkçeye uyarlanan Öznel Kariyer Başarısı Ölçeği, "tanınma” (Ça lıştığım kuruma katkı yapan birisi olarak tanınmaktayım), "işin niteliğ i" (İşimi en yüksek standartlarda yapan biri olarak bilinmekteyim), "işin anlamlılı̆̆ (Yaptığım işin anlamlı bir iş olduğunu düşünmekteyim), “etki” (Verdiğim kararlar çalıştığım kurumu etkilemektedir), "otantik” (Kendi kariyer yolumu kendim seçtim), "kişisel yaşam" (Arkadaşlarıma ve aileme istediğim kadar vakit ayırabilmekteyim), "büyüme ve gelişme" (Alanımdaki, güncel değişiklikleri takip etmekteyim) ve "tat min" (Kişisel olarak kariyerim tatmin edici) olmak üzere sekiz alt boyuttan oluşmaktadır. Her boyutta üç madde olmak üzere toplam 24 madde yer almaktadır. Araştırmaya katılanlardan bu yargı cümlelerine hangi oranda katıldıklarını beşli Likert tipi ölçek üzerinde, 1 (Kesinlikle Katılmiyorum) ile 5 (Tamamen Katılıyorum) arasında değişen bir sıklık aralığ ında işaretleme leri istenmiştir.

Mevcut çalışmada elde edilen verilerin değerlendirilmes inde Stata 14.0 paket programı kullanılmıştır. Ölçeğin iç tutarlılığ 1 iç in Cronbach Alfa katsayısı hesaplanmış ve ölçeğin yapısal o larak geçerliliğini sağlamak için ise doğrulayıcı faktör analizi yapılmıştır. Doğrulayıcı faktör analizi neticesinde yazında kabul edilen eşik değerleri elde edilememiş ve ölçeklerin yapıları doğrulanamamış olmas1 durumunda, ölçek maddelerinin ve faktörlerin arasındaki ilişki örüntüsünü keşfetmek maksadıyla keşfedici faktör analizi yapılmıştır
(Gürbüz \& Şahin, 2014). Keşfedici faktör analizi uygulanırken yapısal geçerliliğini tespit etmek amaciyla temel bileşenler (principal component) analizi ve "varimaks" eksen döndürmesi tekniğ $i$ kullanılmıştır.

Bulgular ve Tartışma. Öznel kariyer başarısı ölçeğini oluşturan sekiz alt boyutun güvenilirlik analizi, Cronbach alfa $(\alpha)$ değeri hesaplanarak yapılmıştır. Ölçeğin alt boyutların in Cronbach alfa

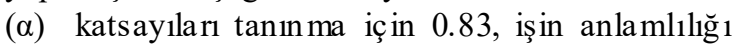
için 0.78 , etki için 0.62 , işin niteliği için 0.87 , otantik için 0.76 , kişisel yaşam için 0.81 , büyüme ve gelişme iç in 0.82 ve tatmin iç in 0.92 olarak elde edilmiştir. $\mathrm{Bu}$ değerler her alt boyuta ait üçer maddenin iç tutarlılık güvenilirliğini göstermektedir. Ölçekteki maddeler arasında iç tutarlılık değerlerinde etki $(0,62)$ boyutu hariç kabul edilebilir değer olan 0.70 'ten yüksektir (Nunnally, 1978). Ayrıca ölçeğin toplam Cronbach Alfa katsayısının 0.91 olarak hesaplanmıştır.

Sekiz alt boyut ve toplam 24 maddeden oluşan "Öznel Kariyer Başarısı" ölçeğinin (üç madde tanınma, üç madde işin niteliği, üç madde işin anlamlılığ 1 , üç madde etki, üç madde otantik, üç madde kişisel yaşam, üç madde büyüme ve gelişme ve üç madde tatmin) birinci düzey faktöriyel yapıs1 test edilmiştir. 5"li likert ölçeğinde, 366 denekten toplanan verilerin normal dağılım göstermesi nedeni ile maksimum likelihood hesaplama yöntemi kullanılarak kovaryans matrisi oluşturulmuştur (Kline, 2011). Birinci düzey DFA neticesinde elde edilen uyum iyiliğ $\mathrm{i}$ değerleri ile $\left(\mathrm{X}^{2} \quad[224\right.$, $\mathrm{N}=366]=3270.179 ; \mathrm{p}<0.01 ; \mathrm{x}^{2} / \mathrm{sd}=14.59$; RMSEA = 0.193; $\mathrm{CFI}=0.63$; TLI=0.55) önerilen sekiz faktörlü modelin veri ile uyumlu olmadığı görülmüştür. Bunun üzerine bazı düzeltmeler yapılmış ancak yine de yazında kabul gören eşik değerlere ulaşılamamıştır. Bu nedenle sekiz faktörlü modelin faktöriyel yapısını keşfetmek için temel bileşenler (principle component) analizi ve varimax eksen döndürmesi tekniği kullanilarak KFA uygulanmıştır. KFA neticesinde, Kaizer-MeyerOlkin (KMO) örneklem yeterlilik değerin in 0.7568 olduğu ve örneklemin büyüklügünün faktör analizi için yeterli olduğu tespit edilmiştir. Barlet küresellik testinin anlaml1 olmas1 $\left(\mathrm{X}^{2}(224)=3270.179\right.$, $\mathrm{p}<0.001)$ maddeler arasindaki korelasyon ilişkilerinin faktör analizi için uygun olduğuna işaret etmektedir. KFA"da özdeğerlerin (eigenvalues) birden büyük olması durumunda faktörlerin oluşması sağlanmıştır. KFA analizi neticesinde 14 faktörlü bir sonuç elde edilmiştir. Yamaç serpinti grafiğ $i$ ve faktörlerin açıkladıkları varyanslar dikkate alınarak sekiz faktörlü bir yapının uygun olduğu görülmüştür. Ancak iki faktörün (Tanınma ve Etki faktörleri toplam altı madde) çapraz yüklenme eğilimi gösterdiği tespit 
Tablo 1: Tanımlayıcı İstatistik Tablosu

\begin{tabular}{lccccc}
\hline & $\mathbf{N}$ & Min. & Maks. & Ort. & SS. \\
\hline Tanınma & 373 & 1,33 & 5,00 & 4,35 & 0,74 \\
İșin Anlamlılı̆̆ & 373 & 1,00 & 5,00 & 3,99 & 0,99 \\
Etki & 373 & 1,00 & 5,00 & 3,42 & 1,14 \\
İșin Niteliği & 373 & 1,00 & 5,00 & 4,10 & 0,80 \\
Otantik & 373 & 1,00 & 5,00 & 3,50 & 1,19 \\
Kişisel Yaşam & 373 & 1,00 & 5,00 & 3,36 & 1,21 \\
Büyüme ve Gelișme & 373 & 1,33 & 5,00 & 4,09 & 0,86 \\
Tatmin & 373 & 1,00 & 5,00 & 3,45 & 1,22 \\
\hline
\end{tabular}

edilmiştir. Bunun dıșında dört ayrı faktördeki birer maddenin (İşin anlamlılığ 1 üçüncü madde, Otantik ikinci madde, Büyüme ve gelişme ikinci madde, Kişisel yaşam birinci madde) de çapraz yüklenme eğilimi gösterdiği görülmüştür.

Kamu örneklemi kullanılarak yapılan analizler neticesinde, ölçeğin boyutlarının güvenilirlik değerlerinin Shockley ve arkadaşlarının (2015) çalış masına kıyasla düşük olduğu ve öne sürdükleri sekiz boyutlu faktöriyel yapısının doğrulanmadığ 1 tespit edilmiştir. Bunun önemli nedeninin, kamu kurumlarının bazı özelliklerinden dolayı öznel kariyer başarısının yazında bahsedildiği gibi olmamasından kaynaklanmaktadır. Çünkü Weber ideal bürokrasinin niteliklerini örgütlenmede hiyerarşi, evrensellik ve objektiflik ilkelerin in temel alınmasın1, işe seçme ve terfi kararlarının bilgi, beceri ve liyakate dayalı olması gerektiğini belirtmektedir. Ancak günümüzde bu hususlardan uzak bir yapının olması kamu çalışanlarının öznel kariyer başarısı algısında olumsuzluk oluşturmaktadır. Ayrıca Feld man ve Weitz (1988)"e göre işgörenlerin kariyer platosuna girmesine örgütsel özellikler ve bireysel yetersizlikler neden olmaktadır. $\mathrm{Bu}$ açıdan bakıldı̆̆ında kamu kurumlarının dikey yapılı olması nedeniyle işgörenlerin tepeye ulaşması çok zaman almaktadır. $\mathrm{Bu}$ durum da işgörenlerin öznel kariyer başarı algısında olumsuzluk oluşturmaktadır. Kamuda çalışan işgörenlerden elde edilen verilerle yazında kabul edilen eşik değerler elde edilememiş ve ölçeğin yapıs1 doğrulanamaması nedeniyle özel sektörde çalışan işgörenlerden oluşan ikinci örneklemden veri toplan mıştır.

\subsubsection{Araştırma II}

Örneklem. Çalışmanın ikinci ö rneklemi, bilişim ve sağllk sektöründe görev yapan ve kolayda örneklem tekniği ile seçilen 373 katılımcıdan oluşmaktadır. Katılımc1ların 262' si erkek (\% 70), 111'i kadındır(\% 30) ve yaşları 17 ile 48 arasında değişmektedir. Bireylerin yaş ortalaması 28,90 olup, \% 51'i evli, \% 49'u bekârd ır. Eğitim düzeyi açısından bakıldığ inda \% $1^{\prime}$ i doktora, \% 18 'i yüksek lisans, \% 47'si lisans, \% 19'u ön lisans ve \% 15 'i lise mezunudur. Bireylerin ortalama hizmet süreleri 6 yıl olarak belirlenmiştir. Kolayda örneklem metodunun seçildiği çalışma için anket yöntemi kullanılmış olup anketlerin 181'i internet üzerinden çevrimiçi anket tekniği ve 192'si yüz yüze ic ra edilmiştir.

Veri Toplama Aracı ve İşlem. Shockley ve ark. (2015) tarafindan geliştirilen Öznel Kariyer Başarısı Ölçeğ $\mathrm{i}$, bilişim ve sağlık sektöründe görev yapan işgörenlerden oluşan ikinci örnekleme de uygulanmıştır. Ölçeğin iç tutarlılı̆̆ 1 için Cronbach Alfa katsayısı hesaplanmış ve ölçeğin yapısal olarak geçerliliğini sağlamak için ise doğrulayıcı faktör analizi yapılmış tır

Bulgular ve Tartışma. Bilişim ve sağlık sektöründe görev yapan katılımeıların öznel kariyer başarısı ölçeğinin alt boyutlarından almış oldukları puan ortalamaları Tablo 1'de sunulmaktadır. Buna göre katılımcıların öznel kariyer başarı ölçeğinden ortalamadan (Ort.=3) daha yüksek değerler aldıkları görülmektedir.

Öznel kariyer başarısı ölçeğini oluşturan sekiz alt boyutun güvenilirlik analizi, Cronbach alfa $(\alpha)$ 
Tablo 2: Öznel Kariyer Başarısı Boyutlarının Güvenilirlik Katsay1ları

\begin{tabular}{lccc}
\hline Ölçek Boyutları & $\begin{array}{c}\text { Shockley ve } \\
\text { ark. (2015) } \\
(\boldsymbol{\alpha})\end{array}$ & $\begin{array}{c}\text { 1.Örneklem } \\
\text { (Kamu Kurumu) }\end{array}$ & $\begin{array}{c}\text { 2. Örneklem } \\
\text { (Özel Sektör) } \\
(\boldsymbol{\alpha})\end{array}$ \\
\hline Tanınma &, 78 &, 83 &, 85 \\
İșin Anlamllı̆̆ı &, 89 &, 78 &, 82 \\
Etki &, 82 &, 62 &, 85 \\
İșin Niteliği &, 86 &, 87 &, 79 \\
Otantik &, 81 &, 76 &, 85 \\
Kișisel Yaşam &, 75 &, 81 &, 86 \\
Büyüme ve Gelişme &, 87 &, 82 &, 87 \\
Tatmin &, 92 &, 92 &, 91 \\
\hline
\end{tabular}

( $\alpha=$ Cronbach Alfa)

değeri hesaplanarak yapılmıştır. Alt boyutlara ait güvenilirlik $(\alpha)$ katsayıları Tablo 2'de sunulmaktadır. $\mathrm{Bu}$ değerler her alt boyuta ait üçer maddenin iç tutarlılık güvenilirliğini göstermektedir. Ölçekteki maddeler arasında iç tutarlılık değerlerinde ilk örnekleme ait etki $(0,62)$ boyutu hariç kabul edilebilir değer olan 0.70'ten yüksektir (Nunnally, 1978). Ayrıca ölçeğin toplam Cronbach Alfa katsayısı ilk örneklem için 0,91, ikinci örneklem iç in ise 0,94 olarak hesaplanmıştır.

Sekiz alt boyut ve toplam 24 maddeden oluşan "Öznel Kariyer Başarısı" ölçeği beşli likert ölçeğinde, 373 denekten toplanan verilerin normal dağılım göstermesi nedeni ile maksimum likelihood hesaplama yöntemi kullanılarak kovaryans matrisi oluşturulmuştur (Kline, 2011). Ölçeğ in birinci düzey doğrulayıcı faktör analizi DFA sonuçlarına ilişkin parametre değerlerin in olduğu yol şeması Şekil 1'de sunulmuştur. Birinci düzey DFA neticesinde elde edilen uyum iyiliği değerleri (X2 $[214, \quad \mathrm{~N}=371]=663,35 ; \quad \mathrm{p}<0.01 ; \quad \mathrm{x} 2 / \mathrm{sd}=3,09 ;$ $\mathrm{RMSEA}=0.075 ; \mathrm{CFI}=0.928 ; \mathrm{TLI}=0.907)$ önerilen sekiz faktörlü modelin veri ile uyumlu ve kabul edilebilir olduğunu göstermektedir. $\mathrm{Bu}$ sonuçlar, araştırmadan elde edilen verilerin öznel kariyer başarıs1 ölçeğinin öngörülen kuramsal yapısı (sekiz faktörlü model) ile uyuştuğunu göstermiştir.

\section{GENEL TARTIŞMA VE SONUÇ}

Mevcut çalş̧mada yazında yeni bir kavram olan öznel kariyer başarısı yapısının açıklanmasına odaklanılmış ve bu yapının ölçülmesinde kullanılan bir ölçeğ in ulusal yazına kazandırılması için güvenilirlik ve geçerlilik analizleri iki ayr1 örneklem üzerinden yapılmıștır.

Her iki örneklemde katılımcıların öznel kariyer başarısı ölçeğinin alt boyutlarından almış oldukları puanların ortalamadan (Ort.=3) daha yüksek olduğu görülmektedir. Bu bulgu işgörenlerin genel olarak iş yerlerinde tanınmak istediklerini, yaptıkları işin anlamlı olmasin 1 önemsediklerini, iş yerinde alınan kararlarda pay sahibi olması gerektiğine inandıklarını, işlerinin kalitesinden gurur duyduklarını, kariyer konusunda kendi kararlarının etkin olduğuna inandiklarını, kişisel yaşam ile iş hayatı arasında denge kurdukların1, becerilerini geliştirmeye çalıştıklarını ve kariyerlerini tatmin edici bulduklarını ortaya koy maktadır.

\subsection{Araştırmanın Yazına Katkısı}

Öznel Kariyer Başarısı ölçeğin in güvenilirliği için iç tutarlılık yöntemi kullanılmıştır. Ölçeğin alt boyutlarının iç tutarlılığına ilişkin elde edilen Cronbach Alfa değerlerinin kabul edilebilir sınırlar içinde olduğu görülmüştür. Ölçeğ in toplam Cronbach Alfa katsayısı ise yüksek seviyelerde bulunmuştur. Elde edilen değerler ölçeğin daha önceden yapılan çalışmalardaki değerleriyle paralellik göstermektedir (Shockley vd., 2015). Ölçeğ in bu haliyle iç tutarlılı̆̆ın ın sağlandığ ifade edilebilir. Analiz sonucunda elde edilen güvenilirlik bulguları ölçeğin güvenilirliğ inin iyi seviyelerde olduğunu göstermiştir.

Ölçeğ in yapısal geçerliliğ ini ortaya koymak için DFA yapılmıştır. DFA neticesinde birinci örneklem olan kamu sektöründe çalı̧̧an bireylerde ölçeğin sekiz boyutlu yapısı doğrulanamamıştır. Ancak ikinci örneklem o lan özel sektörde çalışan 


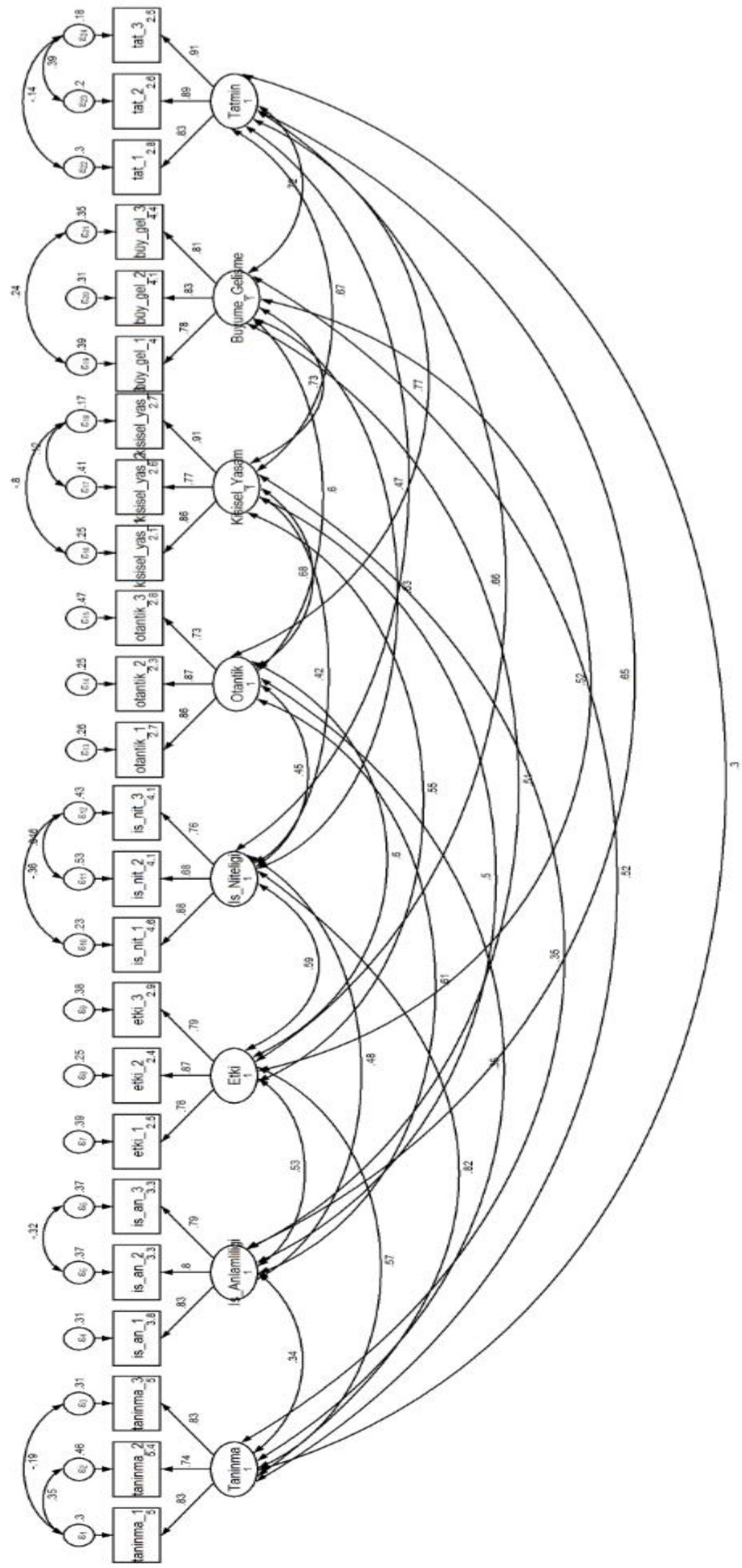


bireylerde uyum iy iliği değerlerin in eşik değerlere uygun olduğu ve sekiz boyutlu yapının doğrulandığ 1 görülmüştür. $\mathrm{Bu}$ durumun birinci örneklemin yapısının öznel kariyer başarısı ölçeğinin alt boyutlarından Tanınma (A mirlerim iyi iş çıkardığımı söylerler) ve Etki (Verdiğim kararlar çalıştığım kurumu etkilemektedir) boyutlarına uygun olmamasindan kaynaklandığ değerlendirilmektedir. Çünkü birinci örneklemdeki katılımcıların yaşları 26 ile 37 arasında değişmekte olup, bu yaşların kamu sektöründe kurumda söz sahibi olmak ve kurumun kararlarında etkili olabilmek için genç yaş olarak değerlendirilmesinden kaynaklandığ 1 düşünülmektedir.

\subsection{Araştırmanın Uygulamaya Katkısı}

Shockley ve arkadaşlarının (2015) çalış masında öznel kariyer başarısının \% 16'sını sadece kariyer bağ $\operatorname{ll}_{1} \breve{g ̆}_{1}$ açıklamaktadır. Kariyer bağ $\operatorname{lll}_{1} \breve{g ̆}_{1}$ işgörenin kariyerine odaklanmaktadır. Ancak iş tatmini, iş devaml1lı̆ 1 , örgütsel bağ $\operatorname{lll}_{1} \mathrm{k}$ ve işten ayrılma niyeti de dâhil olmak üzere örgüt için doğrudan etkileri olan diğer kavramlarla ilişkilidir. $\mathrm{Bu}$ sebeple günümüzün örgütlerin in öznel kariyer başarısının sekiz boyutunu göz önünde bulundurarak yapacakları iş tasarımı ile kariyer bağlılığ1, üretkenlik ve görev süresi konularında olumlu katkılar sağlayabileceği değerlendirilmektedir. Ayrıca örgütlerce işgörenlere daha fazla özerklik sağlanarak, büyümeleri ve gelişmeleri sağlanarak, eğitim ve öğretim olanakları sunularak ve zorlu iş firsatları sunularak otantikliğ in arttırılması ile işgörenlerin kariyer bağlılığın $1 \quad$ arttıracağ 1 düşünülmektedir.

Bununla birlikte ölçeğin boyutlarının önem derecesinin kişiden kişiye farklı olduğu uygulama aşamasında görülmüştür. İşgörenlerin her bir boyutun önem derecesinin kendi kişisel başarı tanımlamalarında kaçıncı sırada olduğunu görmesi hem ö rgüt hem de işgören için önem arz et mektedir. Böylelikle öznel olarak işgörenin ilgi alanlarının belirlenmesine olanak sunacağı değerlendirilmektedir. İşgörenler aras ında oluşan bu farklılıkların işyerlerinde yapılacak olan usta-çırak eşleşmelerinde bile göz önünde bulundurulması gerekmektedir. Çünkü ikili arasındaki uyum örgüt ve işgören için büyük katkılar ortaya çıkarmaktadır.

\subsection{Araştırmanın Kısıtları ve Gelecek Çalış malar a Öneriler}

Çalışmada öznel kariyer başarısı ölçeğiyle ilişkili olarak elde edilen geçerlilik ve güvenilirlik bulguları, araştırmanın yürütüldüğü katılımcılar çerçevesinde sınırlılık taşımaktadır. Öncelikle veri toplanan her iki örneklemin kolayda örneklem metodu ile seçilmesi ve özellikle de ikinci örnekleme ait verilerin yarıya yakının internet üzerinden çevrimiçi olarak toplanması nedeniyle katılımcıları bilgilendirme konusunun eksik kaldı $\breve{g}_{1}$ görülmüştür. İlk örneklemde katılımcıların cinsiyet ve kariyer basamakları arasında bir denge sağlamaya çalışılsa da kurumun yapısından kaynaklanan nedenle denge sağlanamamıstır. Ancak ikinci örneklemde cinsiyet, kariyer basamağı ve eğitim alanında bu denge ilk örnekleme kıyasla iyi olmakla birlikte toplumumuzun iş gücünü yansıtma konusunda eksik kalmaktadır. Bu sebeple bundan sonraki araştırmalarda, ölçeğin özellikle diğer kamu kurumlarında çalışan işgörenlerle kullanılması, geçerlilik ve güvenilirlik konusunda daha güçlü ve genellenebilir bulgulara ulaşılabilmesi açısından önem taşımaktadır.

$\mathrm{Bu}$ çalışma neticesinde, işgörenlerin öznel kariyer başarısını ölçmek için güvenilirliği ve geçerliliğ $i$ sağlanmış bir ölçek Türkçeye uyarlanmıştır. Bu ölçeğin kullanılması, özellikle ülkemizde kariyer başarısı algısında ihmal edilen öznel boyutunun ölçülmesinde ku llanılabilecek ve kurumların kariyer yönetimi sürecinde verecekleri kararlara destek olabilecek çeşitli bilgilerin elde edilmesi ve yönetilmesini kolaylaştırabilecektir. Diğer yandan son haliyle Ek-A'da sunulan ölçek formunun diğer örgütsel alanlarda yapılacak gelecekteki araştırmalara katkı sağlayabileceği değerlendirilmektedir. 


\section{KAYNAKÇA}

Ægisdóttir, S., Gerstein, L.H. \& Çınarbaş, D.C. (2008). Methodological issues in cross-cultural counseling research equivalence, bias, and translations. The Counseling Psychologist, 36(2), 188-219.

Arthur, M. \& Rousseau, D. (1996). The boundaryless career as a new for a new organizational era. New York: Oxford University Press.

Arthur, M., Khapova, S. \& Wilderom, C. (2005). Career success in a boundary less career world. Journal of Organizational Behavior, 26, 177-202.

Bayık, M.E. \& Gürbüz, S. (2016). Ölçek uyarlamada metodoloji sorunu: Yönetim ve örgüt alanında uyarlanan ölçekler üzerinden bir araştırma. Işs ve Insan Dergisi, 3(1), 1-20.

Brislin, R.W., Lonner, W.J. \& Thorndike, R.M. (1973). Cross-Cultural Research Methods, New York, John Wiley-Sons.

Dyke, S.L. \& Murphy, A.S. (2006). How we define success: A qualitative study of what matters most to women and men, Sex Roles, 55(5), 357-371.

Elliott, M. P. (1982). Which way up: career strategies for career advancement. Academy of Management Annual Meeting'de sunulan bildiri, New York.

Erdemir, E. (2008). Yönetim ve örgüt araştırmalarında ölçek kullanımı: Yönetim organizasyon kongre bildirileri örneği. İçinde 16. Ulusal Yönetim ve Organizasyon Kongresi bidiriler kitabı (ss.397-403). İstanbul: İstanbul Kültür Üniversitesi Yay ınevi.

Feldman, C.D. \& Weitz, A.B. (1988). Career plateaus reconsidered. Journal of Management, 14(1), 69-80.

Festinger L. (1954). A theory of social comparison processes. Human Relations, 7, 117-140.

Gattiker, U. \& Larwood, L. (1986). Subjective career success: A study of managers and support personnel. Journal of Business and Psychology, 1(2), 78-94.

Greenhaus, J. (2003). Career dynamics. Handbook of psychology: Industrial and Organizational Psychology, 12, 519-540.

Greenhaus, J., Parasuraman, S. \& Wormley, W. (1990). Effects of race on organizational experiences, job performance evaluations and career outcomes. The Academy of Manag ement Journal, 33, 64-86.

Gürbüz, S. \& Şahin, F. (2014). Sosyal bilimlerde araştırma yöntemleri (2.Baskı). Ankara: Seçkin Yayınc1lik

Hall, D.T. (1996). Protean Careers of the 21st century, Academy of Management Executive, 10(4), 8-16.
Hall, D.T. (2002). Careers in and out of organizations. Thousand Oaks, CA: Sage.

Heslin, P. (2005). Conceptualizing and evaluating career success. Journal of Organizational Behavior, 26, 113-136.

Hughes, E.C. (1937). Institutional Office and the person. American Journal of Sociology, 43, 404-414.

Judge, T.A., Higgins, C.A., Thoresen, C.J. \& Barrick, M.R. (1999). The big five personality traits, general mental ability, and career success across the life span. Personnel Psychology, 52, 621-651.

Kline, R.B. (2011). Principles and practice of structural equation modelling (3. Bask1). London: The Guilford Press.

Ng, T., Eby, L., Sorenson, K. \& Feldman, D. (2005). Predictors of objective and subjective career success. Personnel Psychology, 58, 367-408.

Ng, T.W. \& Feldman, D.C. (2014). Subjective career success: A meta-analytic review. Journal of Vocational Behavior, 85(2), 169-179.

Nunnally, J.C. (1978). Psychometric methods. New York: McGraw Hill.

Parker, P. \& Arthur, M. (2002). Bringing "new science" into careers research. Management, 5, 105-125.

Seibert, S. \& Kraimer, M. (2001). A social capital theory of career success. Academy of Managemet Journal, $44,219-237$.

Shepard, H. (2010). A path with a heart: The Cultural Context of Learning about Careers. Retrieved from appreciativeinquiry .case.edu/uploads/choosin gap athw ithheart.pdf

Shockley, M.K., Ureksoy, H., Rodopman, O.B., Poteat, F.L. \& Dullaghan, R.T. (2015). Development of a new scale to measure subjective career success: A mixed-methods study, Journal of Organizational Behavior, 37(1), 128-153.

Sturges, J. (1999). What is means to succeed: Personal conceptions of career success held by male and female managers at different ages. British Journal of Management, 10, 239-252.

Sullivan, S. \& Baruch, Y. (2009). Advances in career theory and research: Acritical review and agenda for future exploration. Journal of Management, 35(6), 1542-1571.

Turban, D. \& Douhtery, T. (1994). Role of protege personality in receipt of mentoring and career success. Academy of Management Journal, 37, 688702. 
EK - A

\section{ÖZNEL KARIYER B AŞARISI ÖLÇEĞİ}

Kariyeri mi bir bütün olar ak değerlendir diğimde...

Bu bölü mde mesleki kariyerinizi bir bütün olarak değerlendiriniz ve görüşlerinizi temsil eden sayıyı daire içine alarak cevaplayınız.

\begin{tabular}{|c|c|c|c|c|}
\hline 1 & 2 & 3 & 4 & 5 \\
\hline \multirow{2}{*}{ Kesinlikle Kat1lmiyorum } & $\begin{array}{c}\text { Kis men } \\
\text { Katılmiyorum }\end{array}$ & Ortadayım & Kis men & Tamamen Kat 1liyorum \\
\hline
\end{tabular}

\section{Recognition(Tanınma)}

1...A mirlerim iyi iş çıkardığ $1 \mathrm{~m} ı$ söylerler

2...Çalıştığım kurumda işini iy i yapan biri o larak tanın maktayım

3...Çalıştığım kuruma katkılar yapan birisi olarak tanın maktayım.

\begin{tabular}{|l|l|l|l|l|}
\hline 1 & 2 & 3 & 4 & 5 \\
\hline 1 & 2 & 3 & 4 & 5 \\
\hline 1 & 2 & 3 & 4 & 5 \\
\hline
\end{tabular}

\section{Meaningful Work(İşin Anlamlılığı)}

4... Yaptığım işin anlamlı bir iş olduğunu düşünüyorum.

5... Yaptığım işin farklılık yarattığına inanıyorum.

6... Yaptığım işin toplu ma katkı sağladığ $1 \mathrm{n} 1$ düşünüyorum.

\begin{tabular}{|l|l|l|l|l|}
1 & 2 & 3 & 4 & 5 \\
\hline 1 & 2 & 3 & 4 & 5 \\
1 & 2 & 3 & 4 & 5 \\
\hline
\end{tabular}

\section{Influe nce(Etki)}

7... Verd iğim kararlar çalıştığım kuru mu et kileme ktedir.

8...Çalıştı̆̆ım kurumlar önemli konularda benim görüşlerimi dikkate almaktadır.

9... Diğer insanlar önemli kararlar verirken benim tavs iyelerimi hesaba katmaktadırlar.

\begin{tabular}{|c|c|c|c|c|c|}
\hline \multicolumn{6}{|l|}{ Quality Work(İşin Niteliği) } \\
\hline 10...Ortaya koyduğum işin kalitesinden gurur duyuyorum. & 1 & 2 & 3 & 4 & 5 \\
\hline 11...İşimdeki en yüksek ka lite standartların 1 karşıllyorum. & 1 & 2 & 3 & 4 & 5 \\
\hline 12...İșimi en yüks ek standartlarda yapan biri o larak bilin mekteyim. & 1 & 2 & 3 & 4 & 5 \\
\hline
\end{tabular}




\begin{tabular}{|c|c|c|c|c|c|}
\hline \multicolumn{6}{|l|}{ Authenticity(Otantik) } \\
\hline 13... Yaptığ $1 \mathrm{~m}$ iş kişisel ihtiyaçlarımı ve tercih lerimi karşılamaktadır. & 1 & 2 & 3 & 4 & 5 \\
\hline 14...Kariyerimi kendi kontrolü mdey miş gibi düşünüyorum. & 1 & 2 & 3 & 4 & 5 \\
\hline 15...Kendi kariyer yolumu kendim seçtim & 1 & 2 & 3 & 4 & 5 \\
\hline \multicolumn{6}{|l|}{ Personal Life(Kişisel Yaşam) } \\
\hline 16...Arkadaşlarıma ve aileme is tediğim kadar vakit ayırabilmekteyim. & 1 & 2 & 3 & 4 & 5 \\
\hline 17...İşin dışında tatmin ed ici bir hayata sahip olduğumu düşünüyorum. & 1 & 2 & 3 & 4 & 5 \\
\hline $18 \ldots$ Hem iş dışındaki sosyal faaliyetlerimi sürdürüyorum hem de iyi bir ça lışanım. & 1 & 2 & 3 & 4 & 5 \\
\hline \multicolumn{6}{|l|}{ Growth and Development(Büyüme ve Gelişme) } \\
\hline 19... Daha iy i performans gösterebilmek için becerilerimi geliştirmekteyim. & 1 & 2 & 3 & 4 & 5 \\
\hline 20... Alanımdaki güncel değ işiklikleri takip etmekteyim. & 1 & 2 & 3 & 4 & 5 \\
\hline 21... Becerilerimi geliştirerek kendimi sürekli daha iyi seviyelere taşıyorum. & 1 & 2 & 3 & 4 & 5 \\
\hline \multicolumn{6}{|l|}{ Satisfaction(Tatmin) } \\
\hline $22 \ldots$ Kişisel olarak kariyerim tatmin edici & 1 & 2 & 3 & 4 & 5 \\
\hline $23 . .$. Ka riyerim beni heyecanlandırıyor. & 1 & 2 & 3 & 4 & 5 \\
\hline 24...Ka riyerimi oldukça ilgi çekici buluyorum. & 1 & 2 & 3 & 4 & 5 \\
\hline
\end{tabular}

